\title{
RESPON PELAKU USAHA RUMAH POTONG AYAM TERHADAP KEWAJIBAN SERTIFIKASI HALAL
}

\author{
Moch. Khoirul Anwar \\ Universitas Negeri Surabaya. Email : khoirulanwar@unesa.ac.id
}

\begin{abstract}
ABSTRAK
Undang-Undang Republik Indonesia No. 33 Tahun 2014 tentang jaminan produk halal telah diimplementasikan pada tanggal 17 Oktober 2019 bersifat mandatory atau bersifat wajib bagi pelaku usaha, baik pelaku usaha besar, menengah kecil dan mikro. Munculnya Undang-Undang tentang kewajiban halal tersebut menimbulkan berbagai respon positif maupun negatif dari para pelaku usaha, termasuk pelaku usaha Rumah Potong Ayam (RPA). Jenis penelitian yang akan dilaksanakan ini adalah penelitian lapangan (Field Research). Informan dalam penelitian ini adalah pelaku usaha RPA, LPPOM MUI, dan Dinas Peternakan di provinsi jawa timur. Hasil penelitian ini dilihat dari berbagai aspek kognitif, afektif, dan konatif atau psikomotorik dari pelaku RPA yang memiliki skala usaha berbeda-berda.
\end{abstract}

Kata-kata kunci : Respon; Pelaku Usaha; Rumah Potong Ayam; Sertifikasi Halal

\section{ABSTRACT}

The Laws of the Republic of Indonesia Number. 33 of 2014 concerning halal product guarantees implemented on October 17, 2019 to be mandatory or compulsory for businesses, both large, medium and micro businesses. The emergence of the Law on halal obligations has led to a variety of positive and negative responses from business actors, including Chicken Slaughterhouse (CS) business actors. This type of research that will be carried out is field research. The informants in this study were business operators of CS, LPPOM MUI, and the Departement of Animal Husbandry in East Java Province. The results of this study are seen from various cognitive, affective, and conative or psychomotoric aspects of the CS actors who have different business scales.

Keywords: Respons; Businessman; Chickhen Slaughterhouse; Halal Certification

\section{PENDAHULUAN}

Sebagaimana yang telah diketahui, bahwa rapat paripurna DPR RI (Dewan Perwakilan Rakyat Republik Indonesia) pada tanggal 25 September 2014 menyetujui RUU JPH (Rancangan Undang-Undang Jaminan Produk Halal) menjadi Undang-Undang. Kemudian pada tanggal 17 Oktober 2014, Presiden RI Ke-6 Soesilo Bambang Yudhoyono mengesahkan RUU JPH yang telah disetujui DPR RI tersebut menjadi Undang-Undang. Pada hari yang sama juga Menteri Hukum dan Hak Asasi Manusia (HAM) Kabinet Indonesia Bersatu II, Amir Syamsudin mengundangkannya menjadi Undang-Undang Nomor 33 Tahun 2014 tentang Jaminan Produk Halal. 
Sedangkan implementasi dari Undang-Undang tersebut mulai diberlakukan pada tanggal 17 Oktober 2019.

Salah satu keunikan dalam Undang-Undang Jaminan Produk Halal adalah diwajibkannya sertifikasi halal bagi seluruh produk yang beredar di Indonesia, sebagaimana tertuang dalam pasal 4 yang berbunyi "Produk yang masuk, beredar, dan diperdagangkan di wilayah Indonesia wajib bersertifikat halal" (Undang-Undang Tentang Jaminan Produk Halal, 2014). Selain itu, undang-undang ini menugaskan BPJPH (Badan Penyelengara Jaminan Produk Halal) dibawah Kementerian Agama menjadi stake holder utama dalam melaksanakan jaminan produk halal, yang sebelumnya, tugas tersebut dilaksanakan sepenuhnya oleh LPPOM MUI (Lembaga Pengkajian Pangan, Obat-obatan, dan Kosmetika Majelis Ulama Indonesia). Charity (2017) mengungkapkan bahwa dengan lahirnya UU JPH tersebut dapat dimaknai bahwa negara ikut andil dalam menjamin produk halal di Indonesia sehingga adanya pembagian kerja antara pemerintah dan MUI dalam melaksanakan sertifikasi halal. Hal tersebut serupa dengan Malaysia yang memiliki lembaga negara yang bertugas mengeluarkan logo sertifkasi dan menyetujui produk halal secara ketat yaitu JAKIM (Jabatan Kemajuan Islam Malaysia) atau Departemen Pembangunan Malaysia. Namun, pada praktiknya lemabaga non pemerintah seperti MAIN (Majelis Agama Islam Negeri) dan 73 lembaga swasta lainnya dapat melakukan audit produk sesuai dengan hukum syariah (Asa, 2017).

Sebelum diimplementasikan UU JPH, sertifikasi halal dilakukan sepenuhnya oleh LPPOM MUI, mulai pendaftaran hingga pengeluaran sertifikat halal. Walaupun demikian, penentuan kehalalan produk tetap dapat dilakukan oleh Komisi Fatwa MUI. Berikut merupakan data jumlah sertifikat halal yang didaftarkan kepada MUI pada tahun 2014-2019:

Tabel 1. Jumlah Sertifikat Halal

\begin{tabular}{cccc}
\hline Tahun & $\begin{array}{c}\text { Jumlah } \\
\text { Perusahaan }\end{array}$ & $\begin{array}{c}\text { Jumlah Sertifikasi } \\
\text { Halal }\end{array}$ & Jumlah Poduk \\
\hline 2014 & 10.180 & 10.322 & 68.576 \\
2015 & 7.940 & 8.676 & 77.256 \\
\hline 2016 & 6.564 & 7.392 & 114.264 \\
2017 & 7.198 & 8.157 & 127.286 \\
2018 & 11.246 & 17.398 & 204.222 \\
2019 & 13.951 & 11.442 & 166.018 \\
\hline TOTAL & 57.079 & 63.387 & 630.336 \\
\hline
\end{tabular}


Sumber: LPPOM MUI (2019)

Dari tabel di atas dapat dilihat bahwa jumlah pengajuan sertifikasi halal dari para pelaku usaha sampai pertengahan tahun 2019 relatif mengalami peningkatan, walaupun pada saat itu sertifikasi halal hanya bersifat sukarela (voluntery), belum ada kewajiban. Pada tahun tersebut, pertimbangan utama perusahaan yang mengajukan sertifikat halal adalah karena syarat yang diajukan oleh konsumen yang meminta sertifikat halal. Jumlah tersebut terlihat masih sedikit jika dibandingkan dengan jumlah produk yang belum memiliki sertifikasi halal dan beredar di Indonesia.

Proses sertifikasi halal yang dilaksanakan di LPPOM MUI Provinsi Jawa Timur juga menunjukkan trend peningkatan yang relatif sama, baik yang mengajukan sertifikasi halal secara reguler, maupun fasilitasi sertifikasi halal untuk IKM kerja sama instansi pemerintahan terkait. Berikut merupakan tabel pengajuan sertifikasi halal berdasarkan reguler dan IKM:

Tabel 2. Tabel Pengajuan Sertifikasi Halal Berdasarkan Reguler dan IKM

\begin{tabular}{cccccccccc}
\hline \multirow{2}{*}{ Tahun } & \multicolumn{3}{c}{ Jumlah Sertifikat } & \multicolumn{3}{c}{ Jumlah Produk } & \multicolumn{2}{c}{ Jumlah Perusahaan } \\
\cline { 2 - 10 } & Reg & IKM & Total & Reg & IKM & Total & Reg & IKM & Total \\
\hline 2014 & 376 & 275 & 651 & 5897 & 1496 & 7393 & 292 & 274 & 566 \\
2015 & 496 & 389 & 885 & 8348 & 2033 & 10381 & 317 & 373 & 690 \\
2016 & 589 & 343 & 932 & 22686 & 2011 & 24697 & 461 & 331 & 792 \\
2017 & 548 & 431 & 979 & 13061 & 2930 & 15991 & 444 & 420 & 864 \\
2018 & 625 & 742 & 1367 & 13329 & 4349 & 17678 & 515 & 727 & 1242 \\
2019 & 645 & 1187 & 1832 & 19763 & 7457 & 27220 & 540 & 1152 & 1692 \\
$2020($ s.d & & & & & & & & & \\
Maret 2020) & 82 & 74 & 156 & 2067 & 722 & 2789 & 72 & 63 & 135 \\
\hline TOTAL & $\mathbf{4 2 2 6}$ & $\mathbf{3 7 6 5}$ & $\mathbf{7 9 9 1}$ & $\mathbf{1 0 7 1 4 7}$ & $\mathbf{2 2 5 0 8}$ & $\mathbf{1 2 9 6 5 5}$ & $\mathbf{3 4 1 0}$ & $\mathbf{3 6 5 8}$ & $\mathbf{7 0 6 8}$ \\
\hline
\end{tabular}

Sumber: LPPOM MUI Jawa Timur, 2020

Di sisi lain, masih sedikit pelaku usaha RPA (Rumah Potong Ayam) yang mengajukan sertifikasi halal. Berdasarkan data yang dirilis oleh LPPOM MUI Jawa Timur tahun 2019 menunjukkan bahwa jumlah RPA yang sudah bersertifikat halal sejumlah 107 usaha. Apabila dibandingkan dengan jumlah keseluruhan RPA yang ada di Jawa Timur, jumlah tersebut sangat sedikit. Hal ini karena berdasarkan data dari Dinas Peternakan Provinsi Jawa Timur jumlah RPA yang terdaftar yaitu lebih dari 600 usaha, sedangkan masih banyak RPA yang tidak tercatat oleh Dinas Peternakan 
Provinsi Jawa Timur terutama RPA berskala kecil yang tersebar di pasar tradisional ataupun pemotongan ayam secara mandiri di rumah. Anwar (2018) menjelaskan bahwa di antara problem usaha IKM (Industri Kecil Menengah) dalam sertifikasi halal adalah adanya keterbatasan kemampuan SDM dalam menjamin kehalalan produknya, termasuk RPA kecil yang ada di tengah-tengah masyarakat. Kuswantoro et al (2012) mengatakan bahwa masalah IKM secara umum untuk memastikan keterjaminan kualitas produk dari produksi, distribusi, hingga inovasi.

Implikasi dengan adanya UU JPH ini yaitu mewajibkan seluruh produk yang beredar di Indonesia harus memiliki sertifikasi halal, tentunya dengan adanya undang-undang tersebut memiliki dampak tersendiri bagi pelaku usaha RPA, apalagi dalam pasal 19 disebutkan bahwa hewan yang digunakan sebagai bahan produk, wajib disembelih sesuai dengan syariat dan memenuhi kaidah kesejahteraan hewan serta kesehatan masyarakat veteriner (Undang-Undang Tentang Jaminan Produk Halal, 2014). Oleh karena itu, penelitian ini bertujuan mengkaji secara mendalam respon pelaku usaha RPA terhadap kewajiban sertififikasi halal.

\section{METODE PENELITIAN}

Jenis penelitian yang dilakukan merupakan penelitian lapangan (Field Research). Sebagai sumber praktis, penelitian ini dilakukan di Rumah Potong Ayam (RPA) di wilayah Jawa Timur, baik yang telah tersertifikasi ataupun yang belum tersertifikasi halal, serta tempat lain yang berhubungan dengan penelitian ini. Hal ini dilakukan untuk memperoleh data yang bersifat observatif, baik melalui hasil wawancara maupun dokumenter. Penelitian ini juga bersifat kualitatif karena data yang diperoleh dianalisis secara verbal-deskriptif (Moleong, 2006:56).

Objek penelitian ini adalah LPPOM MUI Provinsi Jawa Timur dan RPA di wilayah Jawa Timur. Adapun RPA yang menjadi objek penelitian adalah RPA. Wonokoyo Pasuruan, RPA. Chiomas Adsatwa Sidoarjo, RPA. Phalosari Jombang, RPA. Wahana Sejahtera Jombang, RPA. Restu Abadi Mojokerto, RPA. WSR Sidoarjo, RPA. Syailla Kediri, RPA Barokah Rizzana Batu, RPA Wiranas, Malang, RPA. Chicken Brigade Pasar Sepanjang Sidoarjo, dan RPA. Pasar Wonkoromo Surabaya.

Langkah yang dilakukan setelah data yang diperlukan terkumpul adalah analisis data. Penulis menerapkan analisis isi (content analysis) 
sebagai langkah awal dalam analisis data. Setelah itu, peneliti akan menggunakan analisis sintesis yaitu analisis yang berusaha memeriksa secermat mungkin tesa yang berkembang mengenai sertifikasi halal. Teknik keabsahan data yang digunakan pada penelitian ini adalah teknik triangulasi. Triangulasi merupakan pengecekan data dari sumber yang berbeda-beda dengan cara dan waktu yang berbeda pula (Sugiono, 2016). Untuk menguji kredibilitas data dalam penelitian ini menggunakan triangulasi sumber dan triangulasi teknik.

Triangulasi sumber dilakukan dengan mengecek data yang diperoleh melalui metode wawancara mengenai respon beberapa pelaku usaha Rumah Potong Ayam di wilayah Jawa Timur terkait kewajiban sertifikasi halal. Kemudian hasil wawancara tersebut di cek kembali kepada pelaku usaha RPA yang lain. Data hasil wawancara tersebut dicek dengan metode observasi yaitu melihat langsung fakta di lapangan.

\section{HASIL DAN PEMBAHASAN}

Data di LPPOM MUI Provinsi Jawa Timur menunjukkan bahwa Rumah Potong Ayam (RPA) bersertifikasi halal sampai dengan tahun 2019 sejumlah 107 buah dengan perincian sebagai berikut:

Tabel 3. Jumlah Rumah Potong yang Telah Bersertifikat Halal

\begin{tabular}{lc}
\hline Jenis Rumah Potong & $\begin{array}{c}\text { Jumlah Bersertifikat } \\
\text { Halal }\end{array}$ \\
\hline Rumah Potong Hewan (RPH) & 23 \\
Rumah Potong Unggas (RPU) & 17 \\
Rumah Potong Ayam (RPA) & 67 \\
\hline JUMLAH & $\mathbf{1 0 7}$ \\
\hline
\end{tabular}

Sumber : LPPOM MUI Jawa Timur, 2019

Pengkatagorian jenis rumah potong yang ada pada tabel di atas menunjukkan jenis hewan yang dipotong. RPH (Rumah Potong Hewan) biasa melakukan penyembelihan jenis hewan besar, seperti sapi dan kambing. Rumah Potong Unggas (RPU) melakukan penyembelihan jenis hewan unggas, yaitu ayam potong, ayam kampung, bebek, kalkun dan burung. Sedangkan Rumah Potong Ayam (RPA) hanya melakukan penyembelihan ayam potong dan ayam kampung.

Pelaku RPA di Jawa Timur dapat diklasifikasikan menjadi empat golongan, yaitu mikro, kecil, menengah dan besar. RPA klasifikasi mikro 
melakukan pemotongan ayam maksimal 200 ekor perhari dengan sasaran pemasaran ke pasar tradisional, RPA klasifikasi kecil melakukan pemotongan ayam antara 200-1000 ekor perhari dengan sasaran pemasarannya ke pasar tradisional dan Horeka (Hotel, Restoran,dan Katering) kecil di sekitar RPA. Rumah Potong Ayam klasifikasi sedang melakukan pemotongan ayam sejumlah 1000-10.000 ekor perhari dan pemasarannya ke Horeka (Hotel, Restoran, dan Katering) di dalam provinsi maupun luar provinsi, dan RPA klasifikasi besar melakukan pemotongan ayam di atas 10.000 ekor perhari dengan sasaran pemasarannya tidak hanya Horeka tetapi perusahaan lain yang membutuhkan bahan baku daging ataupun tulang ayam dengan jangkauan luar pulau ataupun ekspor. Selain itu, RPA besar biasanya juga mempunyai peternakan sendiri dan usaha lain berupa pengolahan daging ayam seperti nugget dan sosis.

Secara umum, respon pelaku usaha RPA terhadap kewajiban sertifikasi halal dengan adanya UU JPH No. 33 Tahun 2014 bisa dibagi menjadi tiga respon, yaitu respon kognitif, respon afektif dan respon konatif/psikomotorik.

1. Respon Kognitif Pelaku Usaha RPA (Rumah Potong Ayam) terhadap Kewajiban Sertifikasi Halal.

Secara kognitif, pelaku usaha RPA banyak yang telah mengetahui tata cara pemotongan hewan ayam sesuai dengan syariat Islam, baik syarat pemotongnya maupun tata cara pemotongannya. (Anwar, 2017) menjelaskan bahwa dalam aturan hukum Islam, setiap hewan halal yang hendak dikonsumsi harus dilakukan penyembelihan terhadap hewan tersebut, kecuali ikan dan belalang. Dalam bahasa Arab, penyembelihan diistilahkan dengan al-dzabhu atau al-dzakah yang secara terminologi mempunyai makna menghilangkan nyawa hewan dengan cara memotong tiga urat yang ada di leher melalui saluran pernafasan (tenggorokan/mari'), saluran makan (kerongkongan/hulqum), dan jalan darah (urat nadi /audaj). Penyembelihan seperti ini diharapkan dapat memperoleh daging yang halal dan sehat karena mampu memisahkan darah dari daging sehingga terjaga kesuciannya. Selain itu, manfaat dari penyembelihan tersebut juga bisa mempermudah dan mempercepat kematian, serta menghindari dari penyiksaan terhadap hewan. Menurut Awan dan Rahim (2018) standar industri hewan terrnak memiliki prinsip bahwa hewan juga harus 
diperlakukan secara manusiawi dengan cara meminimalkan rasa takut, rasa sakit, stres dan penderitaan yang dapat disederhanakan dalam "Lima Kebebasan", yaitu: (1) bebas dari kelaparan dan kehausan, (2) bebas dari ketidaknyamanan, (3) bebas dari rasa sakit, cidera, dan penyakit, (4) kebebasan untuk mengekspresikan perilaku normal, dan (5) bebas dari rasa takut dan tertekan.

Tata cara penyembelihan untuk mendapatkan daging ayam yang halal juga terdapat syarat untuk penyembelih. Al-Zuhaili (2009) memaparkan bahwa untuk mendapatkan kesempurnaan kehalalan hewan yang disembelih, maka penyembelihnya disyaratkan seorang muslim, baligh, berakal, laki-laki, dan tidak meremehkan kewajiban sholat lima waktu. Semua ulama sepakat atas kehalalan penyembelihan orang yang memenuhi syarat tersebut.

Walaupun sebagian besar pelaku usaha Rumah Potong Ayam sudah mengetahui tata cara pemotongan secara syariat Islam, tetapi kebanyakan pelaku usaha RPA yang klasifikasi mikro dan kecil tidak mengetahui kewajiban sertifikasi halal sesuai dengan UU JPH No. 33 Tahun 2014. Sedangkan pelaku usaha RPA menengah dan besar sudah mengetahui kewajiban sertifikasi halal sesuai dengan UU tersebut. Dalam pasal 4 dijelaskan bahwa produk yang masuk, beredar, dan diperdagangkan di wilayah Indonesia wajib bersertifikat halal (Undang-Undang Tentang Jaminan Produk Halal, 2014). Secara spisifik juga dijelaskan dalam pasal 19 bahwa hewan yang digunakan sebagai bahan Produk wajib disembelih sesuai dengan syariat dan memenuhi kaidah kesejahteraan hewan serta kesehatan masyarakat veteriner.

Begitu juga dengan pengetahuan tentang tata cara sertifikasi halal sebagai dampak adanya UU JPH No. 33 Tahun 2014, sebagian besar pelaku usaha RPA mikro, kecil dan menengah masih belum mengetahuinya. Sedangkan pelaku usaha RPA besar sudah mengetahuinya walaupun belum semuanya. Sebelumnya, pengajuan sertifikasi halal ditujukan ke LPPOM MUI, tetapi setelah diimplementasikannya UU JPH No. 33 Tahun 2014, pengajuan sertifikasi halal ke BPJPH (Badan Penyelenggara Jaminan Produk Halal) Kementerian Agama Republik Indonesi. Hal itu sesuai dengan pasal 29 yang berbunyi "Permohonan Sertifikat Halal diajukan oleh Pelaku Usaha secara tertulis kepada BPJPH" (Pelaksanaan Undang-Undang Republik Indonesia Nomor 33 Tahun 2014 tentang Jaminan Produk Halal, 
2019).

2. Respon Afektif Pelaku Usaha Rumah Potong Ayam (RPA) terhadap Kewajiban Sertifikasi Halal.

Respon afektif pelaku usaha RPA terhadap kewajiban sertifikasi halal sangat berbeda antara RPA mikro dan kecil dengan RPA Menengah dan besar. RPA menengah dan besar relatif bisa menerima kewajiban tersebut. Pelaku usaha RPA beranggapan bahwa kewajiban sertifikasi halal merupakan suatu konsekuensi dalam menjaga kualitas atau mutu produk yang halal sehingga hal tersebut sangat penting pada kepercayaan konsumen atau masyarakat. Akan tetapi, RPA mikro dan kecil merasa berat dengan kewajiban sertifikasi halal. Alasan yang disampaikan adalah karena biaya sertifikasi halal karena kewajiban sertifikasi halal sedikit banyak akan menambah cost produksi sehingga pada akhirnya akan menaikkan harga produk. Selain itu, konsumen juga belum tentu bisa menerima kenaikan harga tersebut. Para pelaku RPA mikro dan kecil berharap pemerintah ikut menfasilitasi secara gratis sertifikasi halal.

Kewajiban sertifikasi halal merupakan bagian dari upaya perlindungan konsumen muslim dari produk-produk yang diharamkan dalam ajaran Islam. Menurut Anwar (2017) Konsumen muslim juga perlu dilindungi dari produk haram maupun syubhat karena salah satu tujuan perlindungan konsumen adalah menjadikan manusia yang sehat jasmani dan rohani. Perlindungan konsumen juga mempunyai muara pada praktik perdagangan yang tidak jujur (unfair trade practices). Dalam pandangan ini secara tegas dinyatakan bahwa upaya untuk melakukan perlindungan konsumen disebabkan adanya tindakan-tindakan atau perbuatan para pelaku usaha dalam menjalankan aktifitas bisnisnya yang tidak jujur sehingga dapat merugikan konsumen. Walaupun sikap RPA berbeda-beda mengenai kewajiban sertifikasi halal, aka tetapi sikap pelaku usaha RPA dalam segala klasifikasi semuanya setuju tentang pentingnya produk halal bagi bisnis usahanya. Memproduksi barang halal adalah perintah agama Islam yang harus dilakukan. Selain perintah agama, seluruh RPA sepakat pentingnya produk halal adalah sangat berkaitan dengan pemasaran dalam bisnis.

Secara moral, memproduksi produk halal adalah bagian dari kepatuhan seseorang pada ajaran agama Islam, karena halal haram adalah 
persoalan yang prinsip dalam agama Islam sebagaimana firman Allah dalam al-Quran surat al-Baqarah ayat 168 sebagai berikut:

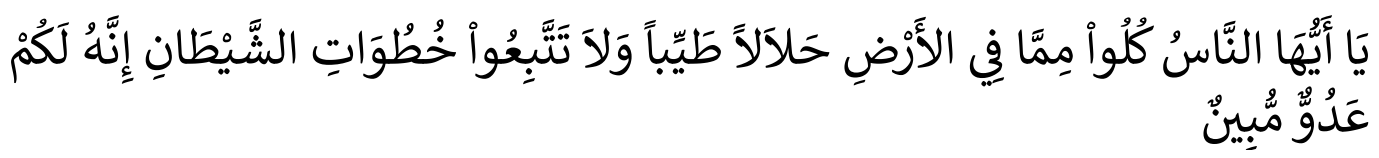

Artinya: "Hai sekalian manusia, makanlah yang halal lagi baik dari apa yang terdapat di bumi, dan janganlah kamu mengikuti langkah-langkah syaitan; karena sesungguhnya syaitan itu adalah musuh yang nyata bagimu".

Ibnu Katsir (2000) menafsirkan ayat ini dengan menyatakan bahwa Allah memerintahkan manusia untuk mengkonsumsi produk yang halal dan bermanfaat, tidak membahayakan tubuh dan akal manusia. Allah melarang manusia mengikuti jejak langkah setan dengan mengkonsumsi makanan atau minuman yang diharamkan Allah. Ketika seseorang mengkonsumsi produk yang halal, maka berarti dia sudah menjaga dirinya dan keluarganya untuk selalu beramal sholih, karena produk yang dikonsumsi seseorang mempunyai dampak dalam kehidupan sehari-hari. Sebagaimana Firman Allah dalam al-Qur'an surat al-Mukminun ayat 51 :

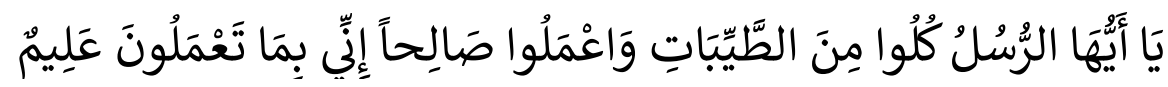

Artinya: "Hai rasul-rasul, makanlah dari makanan yang baik-baik, dan kerjakanlah amal yang saleh. Sesungguhnya Aku Maha Mengetahui apa yang kamu kerjakan".

Al-Maraghi (2000) menafsirkan ayat ini dengan menyatakan bahwa walaupun yang dipanggil dalam ayat di atas adalah para Rasul, tetapi maknanya adalah seluruh manusia. Ibnu Katsir (2000) menafsirkan ayat di atas dengan menjelaskan bahwa ketika sesorang mengkonsumsi produk halal, maka hal itu bisa menolong dirinya untuk mudah melakukan amal sholih.

3. Respon Konatif / Psikomotorik Pelaku Usaha RPA (Rumah Potong Ayam) terhadap Kewajiban Sertifikasi Halal.

Respon konatif pelaku usaha RPA dalam menghadapi kewajiban sertifikasi halal berbeda antara RPA mikro dan kecil dengan RPA menengah dan besar. RPA mikro tidak melakukan tindakan apapun menghadapi kewajiban sertifikasi halal, kecuali menunggu kebijakan fasilitasi sertifikasi halal dari pemerintah. Sedangkan RPA kecil masih berusaha mengajukan sertifikasi halal dengan cara mencari informasi 
tentang tata cara pengajuan sertifikasi halal dan kelengkapan persyaratan, di antaranya mencari informasi tentang sistem manual jaminan halal.

Respon konatif pelaku usaha RPA menengah dan besar dalam menghadapi kewajiban sertifikasi halal diwujudkan dengan mengikutkan petugas pemotong dalam pelatihan tata cara pemotongan hewan sesuai syariat Islam, baik pelatihan yang diadakan oleh pihak lain maupun secara inhouse training. Selain itu, RPA menengah dan besar juga mengikutkan Tim Manajemen Halal dalam pelatihan penyelia halal ataupun pelatihan sistem jaminan halal. Penyelia halal adalah orang yang bertanggung jawab kehalalan produk di perusahaan. Sedangkan sistem jaminan halal adalah prosedur tertulis perusahaan dalam menjaga kehalalan produknya.

Pelatihan penyelia halal menjadi hal yang urgent dalam kewajiban sertifikasi halal, karena secara eksplisit disebutkan dalam pasal 24 bahwa pelaku usaha yang mengajukan sertifikasi halal harus mempunyai penyelia halal (Undang-Undang Tentang Jaminan Produk Halal, 2014). Lebih lanjut dalam pasal 28 dijelaskan bahwa tugas penyelia halal adalah (1) mengawasi proses produk halal (PPH) di perusahaan; (2) menentukan tindakan perbaikan dan pencegahan; (3) mengkoordinasikan $\mathrm{PPH}$; dan (4) mendampingi Auditor Halal Lembaga Pemeriksa Halal (LPH) pada saat pemeriksaan (Undang-Undang Tentang Jaminan Produk Halal, 2014). Dengan adanya tugas yang begitu berat dan kompleks, maka perusahaan mengikutkan karyawannya dalam pelatihan penyelia halal.

Begitu juga dengan sistem jaminan halal yang menjadi syarat bagi pelaku usaha yang mengajukan sertifikasi halal. Anwar (2018) menjelaskan bahwa sistem jaminan halal adalah sistem manajemen terintegrasi yang disusun, diterapkan dan dipelihara oleh perusahaan dalam rangka mengatur bahan, proses produksi, produk, sumber daya manusia dan prosedur dalam rangka menjaga kesinambungan proses produksi halal. Definisi di atas menunjukkan bahwa sistem jaminan halal merupakan sistem yang seharusnya dimiliki oleh perusahaan yang bersertifikat halal yang terdiri dari berbagai elemen yang ada dalam perusahaan tersebut.

Pelatihan tersebut sangat penting bagi perusahaan dalam menyongsong kewajiban sertifikasi halal. Menurut Mathis (2006) Pelatihan merupakan proses untuk tercapainya kemampuan tertentu untuk membantu mencapai terwujudnya tujuan organisasi. Gomes dalam 
Onibala et al. (2017) menuturkan bahwa pelatihan adalah usaha untuk memperbaiki performasi pekerjaan pada suatu pekerjaan tertentu yang sedang menjadi tanggung jawabnya, atau satu pekerjaan yang ada kaitannya dengan pekerjaanya. Dari definisi tersebut menunjukkan bahwa pelatihan penyelia halal dan sistem jaminan halal menjadi hal yang sangat penting bagi perusahaan yang mengajukan sertifikasi halal. Akan tetapi, hal yang terpenting lagi menurut Haryati (2019) evaluasi setelah pelaksanaan pelatihan. Evaluasi ini bisa dilakukan dengan dua cara, yaitu setelah pelaksanan pelatihan, karyawan harus memberikan laporan secara tertulis kepada perusahaan, dan pada bulan keempat setelah pelaksanaan pelatihan, karyawan tersebut akan dievaluasi dalam melakukan pekerjaanya.

\section{SIMPULAN}

Berdasarkan dari hasil penelitian dan pembahasan di atas, dapat diambil kesimpulan bahwa secara kognitif, pelaku usaha RPA menengah ke atas sudah mengetahui kewajiban sertifikasi halal dan tata cara pengurusannya. Sedangkan pelaku usaha RPA mikro dan kecil, banyak yang belum mengetahui. Secara afektif, pelaku usaha RPA menengah dan besar menganggap penting kewajiban sertifikasi halal sebagai konsekuensi dalam menjaga kualitas/mutu produk yang halal. Sertifikasi halal sangat penting untuk menimbulkan kepercayaan pada konsumen. Sedangkan pelaku usaha RPA mikro dan kecil merasa berat dengan kewajiban sertifikasi halal dan berharap pemerintah ikut membantu proses sertifikasi halal secara gratis. Secara konatif atau psikomotorik, pelaku usaha RPA menengah dan besar mempersiapkan dengan matang dan aktif, di antaranya mengikuti atau mengadakan pelatihan sistem jaminan halal, penyelia halal dan sistem pemotongan hewan halal. Sedangkan pelaku usaha RPA mikro dan kecil terlihat pasif dan menunggu instruksi pemerintah.

\section{DAFTAR RUJUKAN}

Al-Maraghi, A. M. (2000). Tafsir al-Maraghi,. In Syirkah Maktabah wa Matba'ah Musthafa al-Babi al-Halabi wa Auladih (p. 28).

Al-Zuhaili, W. (2009). Al-Fiqh al-Islami wa adillatuhu. In Dar al-Fikr (p. 650).

Anwar, M. K., Fahrullah, A., \& Ridlwan, A. A. (2017a). Implementasi 
Nilai-Nilai Syariah Pada Pedagang Muslim Di Indonesia. Prosiding Seminar Nasional PPM Universitas Negeri Surabaya 2017, 546-550.

Anwar, M. K., Fahrullah, A., \& Ridlwan, A. A. (2017b). Sertifikasi Halal Sebagai Upaya Perlindungan Konsumen Muslim (Studi pada Lembaga Pengkajian Pangan Obat-obatan dan Kosmetika Majelis Ulama Indonesia Provinsi Jawa Timur). Prosiding Seminar Nasional PPM Universitas Negeri Surabaya, 538-545.

Anwar, M. K. (2018). The Urgency of Halal Assurance System for Product Reliability. International Journal of Islamic Business and Economics (IJIBEC), 119. https://doi.org/10.28918/ijibec.v2i2.1388

Anwar, M. K., Fahrullah, A., \& Ridlwan, A. A. (2018). The Problems of Halal Certification for Food Industry in Indonesia. International Journal of Civil Engineering and Technology (IJCIET), 9(8), pp. 1625-1632.

https://www.iaeme.com/MasterAdmin/uploadfolder/IJCIET_09_08_162 /IJCIET_09_08_162.pdf

Asa, R. S. (2017). Malaysian halal certification: it's religious significance and economic value. Jurnal Syariah, 25(1), 137-156. https://ejournal.um.edu.my/index.php/JS/article/download/6784/4457/

Awan, J. A. \& Rahim, S. F. (2018). Animal rights and welfare in Islam. International International Journal of Avian $\mathcal{E}$ Wildlife Biology, 3(6), 427430. https://doi.org/10.15406/ijawb.2018.03.00135

Charity, M. L. (2017). Jaminan Produk Halal di Indonesia. Jurnal Legislasi Indonesia, 14(1), 99-108. http://e-jurnal.peraturan.go.id/index.php/jli/article/download/77/pdf

Haryati, R. A. (2019). Analisis Pelaksanaan Program Pelatihan dan Pengembangan Karyawan: Studi Kasus Pada PT Visi Sukses Bersama Jakarta. Widya Cipta - Jurnal Sekretari Dan Manajemen, 3(1), 91-98. https://doi.org/10.31294/widyacipta.v3i1.5185

Undang-Undang Tentang Jaminan Produk Halal., (2014).

Pelaksanaan Undang-Undang Republik Indonesia Nomor 33 Tahun 2014 tentang Jaminan Produk Halal., (2019).

Katsir, I. (2000). Tafsir al-Qur'an al-Adzim. In Al-Faruq al-haditsah li al-Tiba'ah wa al-nasyr (p. 144).

Kuswantoro, F., Rosli, M. M., \& Kader, R. A. (2012). Innovation in Distribution Channel, Cost Efficiency \& Firm Performance : The Case of Indonesian Small \& Medium Enterprise Scales. International Journal 
of Business, Humanities and Technology, 2(4), 23-38. http://www.ijbhtnet.com/journals/Vol_2_No_4_June_2012/4.pdf

Mathis, J. (2006). Human Resource Management. In Salemba Empat. (p. 301). Moleong, L. J. (2006). Metodologi Penelitian Kualitatif. Remaja Rosdakarya.

Onibala, N. R., Tewal, B., \& Sendow, G. M. (2017). the Effect of Education, Training and Career Development To Employee Performance At Kantor Pelayanan Kekayaan Negara Dan Lelang Manado. Pengaruh Pendidikan, Pelatihan Dan Pengembangan Kariri Terhadap Kinerja Pegawai Pada Kantor Pelayanan Kekayaan Negara Dan Lelang Manado, 5(2), 27902798.

https://ejournal.unsrat.ac.id/index.php/emba/article/download/17157/1 6704

Sugiono. (2016). Metode Penelitian Kuantitatif, Kualitatf, dan RED. Alfabeta Bandung. 